\title{
Glucagon Degradation by Human Mononuclear Cells
}

\author{
G.W. Neal ${ }^{1}$, S.S.Solomon ${ }^{1}$, T.P.Shankar ${ }^{1}$ and W.C. Duckworth ${ }^{2}$ \\ ${ }^{1}$ Research and Medicine Services of the Veterans Administration Medical Center, and University of Tennessee Center for the Health Sciences, \\ Memphis, Tennessee and ${ }^{2}$ Veterans Administration Medical Center and Indiana University School of Medicine, Indianapolis, Indiana, USA
}

\begin{abstract}
Summary. Degradation of ${ }^{125}$ I-iodoglucagon by human mononuclear cell preparations including one containing 18\%-27\% monocytes, one consisting of $97 \%$ pure monocytes and one consisting of $98 \%$ lymphocytes was examined. Intact cells were incubated with ${ }^{125}$ I-iodoglucagon and degradation assessed by measuring an increase in trichloroacetic acid soluble products or in non-immunoprecipitable products. The preparation consisting of intact lymphocytes did not degrade glucagon. Glucagon was degraded by preparations containing monocytes and this degradation increased with time. No difference between monocyte degradation as measured by trichloroacetic acid or immunoprecipitation was found. Degradation by intact monocytes and by mononuclear homogenates increased sixfold from $4{ }^{\circ} \mathrm{C}$ to $37^{\circ} \mathrm{C}$. Subcellular fractionation demonstrated that the majority of the neutral
\end{abstract}

glucagon degrading activity was in the $100,000 \mathrm{~g}$ supernatant (cytosol). Kinetic analyses gave $\mathrm{K}_{\mathrm{m}}$ values of $1.1 \times 10^{-5} \mathrm{~mol} / \mathrm{l}$, $7.5 \times 10^{-6} \mathrm{~mol} / \mathrm{l}$, and $1.2 \times 10^{-5} \mathrm{~mol} / 1$ for glucagon degradation by intact mononuclear cells, homogenates, and cytosol, respectively. Inhibitor studies indicated a sulphydryl dependent enzyme was involved in glucagon degradation by both intact cells and cytosol. The monocyte appeared to be the cell responsible for degradation of glucagon by mononuclear cell preparations. The degradation of glucagon under physiological conditions by intact monocytes was mediated by a neutral proteolytic enzyme, primarily localized in the cytosol.

Key words: Glucagon, degradation, monocytes, neutral protease.
The actions of glucagon on sensitive tissues are initiated by binding of the hormone to specific plasma membrane receptors. Activation of the adenylate cyclase system follows the interaction of the hormone-receptor complex giving rise to a cascade of phosphorylation reactions inside the cell which result in the characteristic metabolic response to glucagon [1-3]. Tissues known to be responsive to glucagon include adipocytes and hepatocytes. Recant and co-workers have demonstrated that human mononuclear leucocytes are capable of specifically binding glucagon $[4,5]$. Mononuclear cells are not classically considered to be glucagon sensitive and therefore the significance of these receptors is unknown.

The fate of glucagon bound to responsive tissues is not well known although the hormone can be degraded by a variety of cellular and circulating proteases. In this study, the degradation of glucagon by human mononuclear cell preparations was investigated. Ficoll-Hypaque preparations containing 18\%-27\% monocytes and a $97 \%$ pure monocyte preparation were found to degrade ${ }^{125} \mathrm{I}$-iodoglucagon. In contrast, a $98 \%$ pure lym- phocyte preparation possessed negligible glucagon degrading capacity. In addition, glucagon-degrading systems of intact cells and subcellular fractions were examined and partially characterized.

\section{Materials and Methods}

\section{Materials}

Glucagon was a gift of Dr. R. Chance of Eli Lilly, Indianapolis, Indiana, USA. ${ }^{125}$ I-iodoglucagon was purchased from New England Nuclear Company, Boston, Massachusetts, USA and was uniformly greater than $95 \%$ trichloroacetic acid precipitable and $80 \%$ immunoprecipitable. When ${ }^{125} \mathrm{I}$-iodoglucagon was more than 2 weeks old, it was rechromatographed on Biogel P-30 (Biorad Laboratories, Richmond, California, USA). Chemicals used in the inhibitor studies were purchased from Sigma Chemicals, St. Louis, Missouri, USA and were of reagent grade quality. All other chemicals were purchased commercially and were of reagent grade quality.

\section{Mononuclear Cell Preparations}

Approximately $100 \mathrm{ml}$ of heparinized blood were drawn from fasted normal volunteers and mononuclear cells were isolated using Ficoll- 


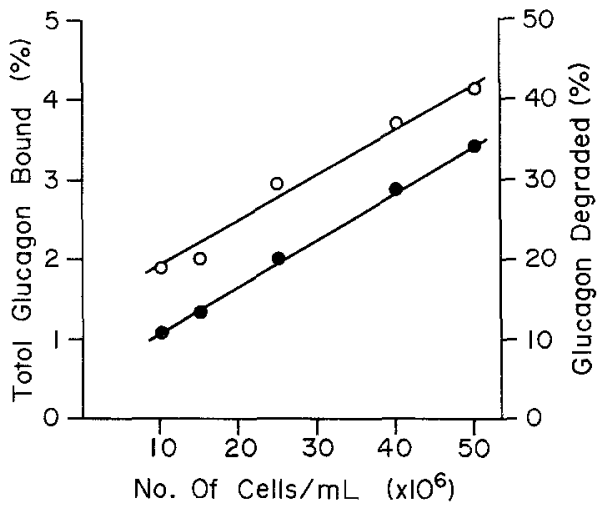

Fig. 1. Glucagon binding and degradation by varying mononuclear cell concentrations (as per $10^{6}$ cells in $500 \mu \mathrm{l}$ ), incubated in $0.1 \mathrm{~mol} / \mathrm{I}$ HEPES- $1 \%$ bovine serum albumin buffer ( $\mathrm{pH} 7.4$ ) for $30 \mathrm{~min}$ at $37^{\circ} \mathrm{C}$. Glucagon degradation was measured by the increase in solubility of ${ }^{125} \mathrm{I}$-iodoglucagon in 5\% trichloroacetic acid. No glucagon-degrading activity was present in the medium after removal of the cells. $\mathrm{O}=$ degradation; = binding

Hypaque [6]. This preparation, which contains both lymphocytes and monocytes, was used for all experiments unless otherwise indicated. To minimize individual differences, each experiment used mononuclear cells freshly isolated from a single subject. The mononuclear cell preparation contained $18 \%-27 \%$ monocytes with the remainder being large lymphocytes. Monocytes were identified by non-specific esterase stain and cell viability was consistently greater than $98 \%$ by trypan blue exclusion [7]. For some studies, purified monocytes (97\%) were prepared by centrifugal elutriation in the laboratory of Dr. A. Postlewaite and purified lymphocytes $(98 \%)$ by a gel filtration technique [8].

\section{Glucagon Degradation by Intact Mononuclear Cells}

Mononuclear cell preparations, as indicated in figure and table legends, were incubated with $10^{-10} \mathrm{~mol} / \mathrm{1}^{125} \mathrm{I}$-iodoglucagon in $0.1 \mathrm{~mol} / \mathrm{l}$ HEPES, $1 \%$ bovine serum albumin $(\mathrm{pH} 7.4)$ in a total volume of $500 \mu \mathrm{l}$ at $37^{\circ} \mathrm{C}$ in a Dubnoff metabolic shaker (Precision Scientific Products, McGraw Park, Illinois, USA) for 30 min. Aliquots of the incubation mixture were then added to $300 \mu \mathrm{l}$ of buffer modified to $2 \%$ bovine serum albumin and centrifuged at $17,000 \mathrm{~g}$ for $5 \mathrm{~min}$. After removal of the supernatant, the pellet was washed again with $500 \mu \mathrm{l}$ of buffer. All supernatants were then combined. Supernatants and pellets were counted in a gamma counter (Packard Instruments, Downers Grove, Illinois, USA) at 58\% efficiency. Cell associated radioactivity, including both bound and internalized ${ }^{125} \mathrm{I}$-iodoglucagon, was defined as counts per min in the pellet divided by counts per min in the pellet plus supernatant $\times 100$. Degradation was assessed by adding $10 \%$ trichloroacetic acid to the supernatant until a final concentration of $5 \%$ trichloroacetic acid was obtained. The precipitate was separated by centrifuging the mixture at $2500 \mathrm{rev} / \mathrm{min}$ and quantifying precipitated intact hormone and soluble degradation products as previously described [9]. To determine if glucagon-degrading activity was leaking from intact mononuclear cells into the incubation mixture, mononuclear cell fractions were incubated in buffer for $30 \mathrm{~min}$, centrifuged, and the supernatant incubated with ${ }^{125} \mathrm{I}$-iodoglucagon as above.

\section{Assay of Degradation by Immunoprecipitation}

Preliminary experiments were performed to determine the amount of rabbit anti-glucagon antiserum (kindly provided by Dr. Joseph Ingraham, Indiana University School of Medicine, Indianapolis, Indiana, USA) necessary for complete precipitation of the ${ }^{125} \mathrm{I}$-iodoglucagon.
In these experiments, the ${ }^{125} \mathrm{I}$-iodoglucagon (kindly provided by $\mathrm{Dr}$. Bruce Frank, Eli Lilly, Indianapolis, Indiana, USA) was 95\% immunoprecipitable by excess antiserum. Mononuclear cells were incubated in $0.1 \mathrm{~mol} / 1$ HEPES- $1 \%$ bovine serum albumin $(\mathrm{pH} 7.4)$ at $37^{\circ} \mathrm{C}$. At the indicated times triplicate $0.5 \mathrm{ml}$ aliquots were taken for measurement of degradation. Cell concentration was $25 \times 10^{6} / 0.5 \mathrm{ml}$. Each $0.5 \mathrm{ml}$ aliquot was centrifuged to precipitate the cells and from each tube $200 \mu \mathrm{l}$ was taken for precipitation with trichloroacetic acid and $200 \mu \mathrm{l}$ taken for immunoprecipitation. For determination of immunoprecipitability, $200 \mu \mathrm{l}$ aliquots containing ${ }^{125} \mathrm{I}$ iodoglucagon in $0.1 \mathrm{~mol} / 1 \mathrm{HEPES}-1 \%$ bovine serum albumin were added to $200 \mu \mathrm{l}$ $0.15 \mathrm{~mol} / 1$ glycine buffer ( $\mathrm{pH} 8.8$ ) containing $\mathrm{N}$-ethylmaleimide (final concentration $2 \mathrm{mmol} / \mathrm{l})$. Rabbit anti-glucagon antiserum $(5 \mu \mathrm{l})$ was added and the tubes incubated at $4{ }^{\circ} \mathrm{C}$ for $48 \mathrm{~h}$. Normal rabbit serum (50 $\mu$ l of $1: 10$ dilution) and goat anti-rabbit gamma globulin $(50 \mu 1)$ were added and the tubes incubated for an additional $24 \mathrm{~h}$ at $4{ }^{\circ} \mathrm{C}$. The tubes were centrifuged and the amount of immunoprecipitable ${ }^{125} \mathrm{I}$ iodoglucagon determined. Appropriate controls containing no antiserum as well as controls containing undegraded glucagon were included.

\section{Mononuclear Cell Homogenates and Subcellular Fractionation}

Mononuclear cell preparations were homogenized in $0.35 \mathrm{~mol} / 1 \mathrm{su}-$ crose in a glass on glass Dounce homogenizer (Arthur H. Thomas Company, Philadelphia, Pennsylvania, USA). The homogenates were then placed in a $500 \mu 1$ volume of HEPES-bovine serum albumin at $\mathrm{pH} 7.4$ and incubated for $30 \mathrm{~min}$ at $37^{\circ} \mathrm{C}$. The reaction was terminated by addition of sufficient trichloroacetic acid to achieve a final concentration of $5 \%$.

In other studies, subcellular fractions were obtained by centrifuging the homogenates at $500 \mathrm{~g}$ for $30 \mathrm{~min}$. The resulting supernatant was then centrifuged at $30,000 \mathrm{~g}$ for $30 \mathrm{~min}$ and separated from the pellet. Finally, centrifugation at $100,000 \mathrm{~g}$ for $30 \mathrm{~min}$ yielded a $100,000 \mathrm{~g}$ pellet and cytosolic supernatant. Neutral glucagon-degrading activity was determined on each fraction using HEPES-bovine serum albumin buffer (pH 7.4). Acidic or lysosomal activity was measured after treating each fraction with $\mathrm{NaAc}(0.1 \mathrm{~mol} / \mathrm{l}), \mathrm{NaCl}$ $(0.1 \mathrm{~mol} / 1), 0.1 \%(\mathrm{v} / \mathrm{v})$ Triton $\mathrm{X}-100$ at $\mathrm{pH} 4.5$ for $12 \mathrm{~h}$ to lyse the lysosomes $[10]$.

\section{$K_{m}$ Determinations}

Kinetic analyses were performed on glucagon-degrading activity from intact homogenized cells, and cytosol using standard ${ }^{125}$ I-iodoglucagon $\left(1 \times 10^{-10} \mathrm{~mol} / 1\right)$ and varying concentrations of unlabelled glucagon to obtain initial rates. The data were analysed by linear regression.

\section{Results}

\section{Glucagon Degradation by Intact Cells}

The effect of total number of mononuclear cells on the cell association and degradation of glucagon is illustrated in Figure 1. Both total cell associated radioactivity and degradation were linearly related to cell number. No degrading activity was present in the supernatant after removal of the cells.

Mononuclear cells incubated for various times between 5 and 120 min demonstrated a time-dependent increase in glucagon degradation (Fig. 2). Extensive metabolism of glucagon is reflected by the $50 \%$ degradation seen at $90 \mathrm{~min}$. In these experiments, prolonged 


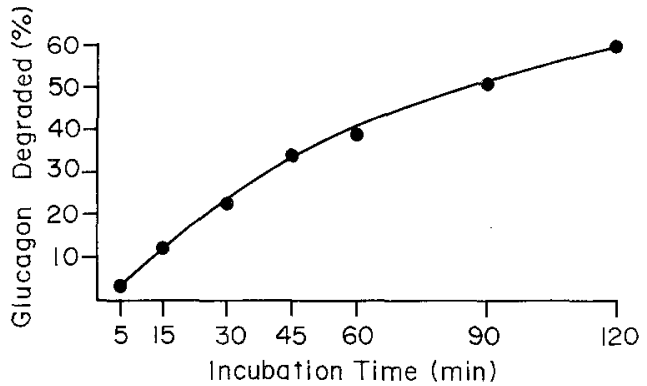

Fig. 2. Glucagon degradation at increasing incubation times. Mononuclear cells $\left(25 \times 10^{6}\right.$ in $500 \mu 1$ buffer as described in Figure 1) were incubated for varying times at $37^{\circ} \mathrm{C}$. The incubation mixture after removal of the cells degraded $20 \%$ of the total glucagon degraded by the cells

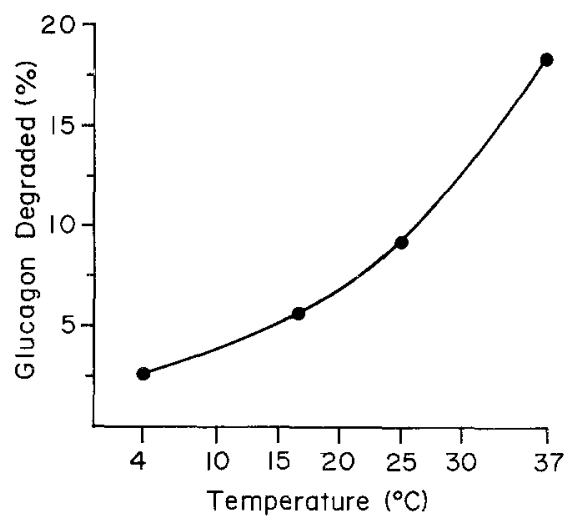

Fig. 3. Temperature effect on glucagon degradation. A volume of $500 \mathrm{\mu l}$ of buffer as described in Figure 1 containing $25 \times 10^{6}$ cells and ${ }^{125} \mathrm{I}$-iodoglucagon was incubated for $30 \mathrm{~min}$ at the indicated temperatures. No degrading activity was present in the medium after removal of the cells

incubation resulted in leakage of degrading activity in the supernatant accounting for about $20 \%$ of the total glucagon degraded.

Glucagon degradation was also temperature dependent with very little degradation at $4^{\circ} \mathrm{C}$ and a sixfold increase over a range of $4^{\circ}-37^{\circ} \mathrm{C}$. (Fig. 3).

The effect of trichloroacetic acid precipitation on glucagon degradation is shown in Table 1. Assay of glucagon degradation by either trichloroacetic acid precipitability or by immunoprecipitability gave comparable results. These data suggest that the intact monocyte produced minimal amounts of degraded material which precipitated with trichloroacetic acid but did not react with glucagon antiserum.

\section{Glucagon Degradation by Mononuclear Cell Homogenates}

Homogenized mononuclear cell preparations degraded 10-20 times more glucagon than intact cells (see below). Figure 4 shows the effect of cell number on glucagon degradation by homogenates. Very rapid proteolysis was seen with almost complete degradation at $30 \mathrm{~min}$
Table 1. A comparison of immunoprecipitation and trichloroacetic acid precipitation for assessing ${ }^{125} \mathrm{I}$-iodoglucagon degradation by human monocytes

\begin{tabular}{lll}
\hline Time & \multicolumn{2}{l}{${ }^{125}$ I-iodoglucagon degradation } \\
\cline { 2 - 3 } & $\begin{array}{l}\text { Soluble in trichloroacetic acid } \\
(\%)\end{array}$ & $\begin{array}{l}\text { Non-immunoprecipitable } \\
(\%)\end{array}$ \\
\hline 15 & 11.6 & 14.8 \\
30 & 19.6 & 20.9 \\
60 & 34.4 & 32.6 \\
120 & 51.6 & 51.2 \\
\hline
\end{tabular}

Mononuclear cells were incubated at $37^{\circ} \mathrm{C}$ for the indicated times. Aliquots were centrifuged to precipitate the cells and degradation measured by precipitation with trichloroacetic acid and immunoprecipitation as described in Methods

Table 2. Subcellular distribution of glucagon degrading activity in human mononuclear cell homogenates

\begin{tabular}{lcc}
\hline Fraction & $\begin{array}{l}\text { Glucagon degraded } \\
(\mathrm{fmol} / \mathrm{l})^{\mathrm{a}}\end{array}$ & $\begin{array}{l}\text { Total } \\
\text { activity }(\%)\end{array}$ \\
\hline Neutral $\mathrm{pH}$ & & \\
Homogenate & 499.00 & 100 \\
$500 \mathrm{~g}$ pellet & 57.2 & 11.2 \\
$30,000 \mathrm{~g}$ pellet & 61.6 & 12.1 \\
$100,000 \mathrm{~g}$ pellet & 17.8 & 3.5 \\
$100,000 \mathrm{~g}$ supernatant & 374.0 & 73.2 \\
Acidic pH & & \\
Homogenate & 97.5 & 100 \\
$500 \mathrm{~g}$ pellet & 151.0 & 155.0 \\
$30,000 \mathrm{~g}$ pellet & 10.3 & 0 \\
$100,000 \mathrm{~g}$ pellet & 0 & 0 \\
$100,000 \mathrm{~g}$ supernatant & 0 &
\end{tabular}

${ }^{a}$ For $5 \times 10^{6}$ cells at $37^{\circ} \mathrm{C}$ for $30 \mathrm{~min}$. Glucagon concentration $10^{-9} \mathrm{~mol} / 1$

with high cell number concentrations. Degradation appeared to be linearly associated only at low cell numbers and the time course of glucagon degradation reached a plateau at $45 \mathrm{~min}$ (data not shown). Similar to the intact cells, degrading activity increased sixfold from $4{ }^{\circ} \mathrm{C}$ to $37^{\circ} \mathrm{C}$ in the homogenates (Fig. 5).

\section{Subcellular Distribution of Glucagon-Degrading Activity}

Neutral and acidic glucagon-degrading activity was measured in the mononuclear cell homogenates as well as the $500 \mathrm{~g}, 30,000 \mathrm{~g}$, and $100,000 \mathrm{~g}$ pellets and in the $100,000 \mathrm{~g}$ supernatant (cytosol). Neutral degrading activity was found in each subcellular fraction (Table 2) with $73 \%$ located in the cytosolic fraction. Total neutral activity recovered from the subcellular fractions agreed well with the quantity present in the homogenate. Acidic activity is primarily lysosomic in nature and, accordingly, the $500 \mathrm{~g}$ pellet contained almost all of the acidic activity with none present in the cytosolic fraction. The fact that recovery of acidic activity in the subcellular fractions was almost double that found in the homogenate is probably due to the removal of cytosolic inhibi- 


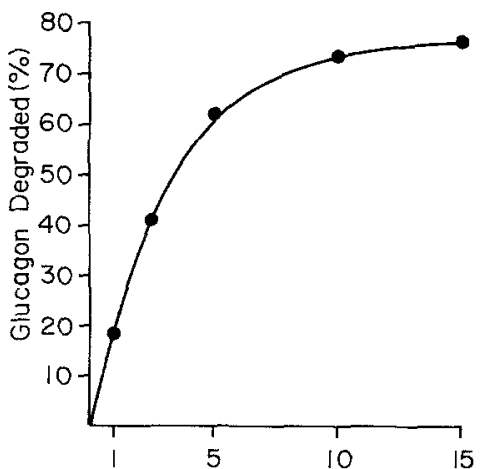

No. Of Homogenized Cells $/ \mathrm{mL}\left(x \mid 0^{6}\right)$

Fig.4. Glucagon degradation by varying concentrations of homogenized mononuclear cells. The homogenates were incubated with glucagon in a total volume of $500 \mu \mathrm{l}$ for $30 \mathrm{~min}$ at $37^{\circ} \mathrm{C}$

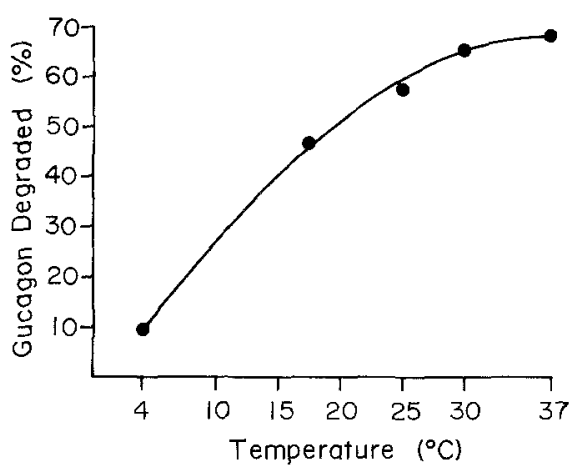

Fig. 5. Effect of temperature on glucagon degradation by homogenized mononuclear cells. A volume of $500 \mu \mathrm{l}$ containing $5 \times 10^{6}$ cells was incubated for $30 \mathrm{~min}$ at various temperatures

Table 3. Summary of kinetic constants for glucagon degradation by intact human mononuclear cells and by homogenates and cytosolic fraction of mononuclear cells

\begin{tabular}{llcl}
\hline Source of Activity & $\begin{array}{l}\mathrm{K}_{\mathrm{m}} \\
\left(\times 10^{-5} \mathrm{~mol} / \mathrm{l}\right)\end{array}$ & $\begin{array}{l}\mathrm{V}_{\max } \\
\left(5 \times 10^{6} / 30 \mathrm{~min}\right)\end{array}$ & $r$ \\
\hline Intact cells & 1.11 & $3.45 \times 10^{-10}$ & 0.9999 \\
Homogenates & 0.75 & $7.82 \times 10^{-10}$ & 0.9956 \\
Cytosol & 1.18 & $12.0 \times 10^{-10}$ & 0.9998 \\
\hline
\end{tabular}

tors of lysosomal enzymes in the fractionation process. Note that the neutral glucagon-degrading activity comprised $75 \%$ of the total cellular glucagon-degrading activity in these assays.

\section{Kinetics of Glucagon Degradation}

Intact mononuclear cells, homogenized mononuclear cells, and cytosol fractions gave linear LineweaverBurke plots for glucagon degradation. Table 3 summarizes the kinetic constants derived by linear regression analysis. $\mathrm{K}_{\mathrm{m}}$ values of $1.1 \times 10^{-5} \mathrm{~mol} / \mathrm{l}$, $7.5 \times 10^{-6} \mathrm{~mol} / \mathrm{l}$ and $1.2 \times 10^{-5} \mathrm{~mol} / 1$ were obtained for intact cells, homogenates and cytosol, respectively. In-
Table 4. Inhibitors of glucagon degradation by intact human mononuclear cells and by cytosol from mononuclear cells

\begin{tabular}{|c|c|c|c|}
\hline $\begin{array}{l}\text { Inhibiting } \\
\text { compound }\end{array}$ & $\begin{array}{l}\text { Concentration } \\
(\mathrm{mmol} / \mathrm{l})\end{array}$ & $\begin{array}{l}\text { Glucagon } \\
\text { degrading } \\
\text { activity } \\
\text { (intact cells) }\end{array}$ & Cytosol $^{\mathrm{b}}$ \\
\hline $\begin{array}{l}\text { N-ethylmaleimide } \\
\text { P-hydroxy- } \\
\text { mercuribenzoate }\end{array}$ & $\begin{array}{l}0.2 \\
0.1\end{array}$ & $\begin{array}{l}0 \\
0\end{array}$ & $\begin{array}{l}0 \\
0\end{array}$ \\
\hline EDTA & $\begin{array}{l}1.0 \\
5.0\end{array}$ & $\begin{array}{l}46 \\
39\end{array}$ & $\begin{array}{l}71 \\
67\end{array}$ \\
\hline Vinblastine & $\begin{array}{l}0.1 \\
0.5\end{array}$ & $\begin{array}{l}73 \\
69\end{array}$ & $\begin{array}{l}63 \\
54\end{array}$ \\
\hline Chloroquine & $\begin{array}{l}0.1 \\
2.0\end{array}$ & $\begin{array}{l}86 \\
57\end{array}$ & $\begin{array}{l}67 \\
43\end{array}$ \\
\hline Lidocaine & $\begin{array}{l}1.0 \\
5.0\end{array}$ & $\begin{array}{r}94 \\
102\end{array}$ & $\begin{array}{l}48 \\
29\end{array}$ \\
\hline Aprotinin (Trasylol) & $\begin{array}{r}500 \mathrm{KIU} / \mathrm{ml} \\
5000 \mathrm{KIU} / \mathrm{ml}\end{array}$ & $\begin{array}{l}59 \\
66\end{array}$ & $\begin{array}{l}88 \\
87\end{array}$ \\
\hline Pepstatin & $\begin{array}{l}0.1 \\
0.5\end{array}$ & $\begin{array}{l}60 \\
56\end{array}$ & $\begin{array}{l}67 \\
45\end{array}$ \\
\hline Bacitracin & $\begin{array}{l}0.1 \\
1.0\end{array}$ & $\begin{array}{l}27 \\
25\end{array}$ & $\begin{array}{l}34 \\
29\end{array}$ \\
\hline Methylamine & $\begin{array}{r}1.0 \\
10.0\end{array}$ & $\begin{array}{l}63 \\
13\end{array}$ & $\begin{array}{l}69 \\
20\end{array}$ \\
\hline Dansylcadaverine & $\begin{array}{l}0.1 \\
0.5\end{array}$ & $\begin{array}{r}13 \\
0\end{array}$ & $\begin{array}{l}49 \\
22\end{array}$ \\
\hline
\end{tabular}

a Pre-incubation for $15 \mathrm{~min}, 5 \times 10^{6}$ at $37^{\circ} \mathrm{C} 30 \mathrm{~min}$. All solutions (pH 7.4) after addition of all components; ${ }^{b} 1 \times 10^{6}$ cell equivalents, same conditions

sulin was found to be a competitive inhibitor of the degradation of glucagon by intact mononuclear cells with a $\mathrm{K}_{\mathrm{I}}$ value of $3.6 \times 10^{-7} \mathrm{~mol} / 1$ (Fig. 6 ).

\section{Inhibitor Studies}

To ascertain the nature of the cellular degrading enzymes, intact cells and cytosol fractions were examined for sensitivity to various inhibitors (Table 4). N-ethylmaleimide and p-hydroxymercuribenzoate totally inhibited glucagon degradation by both intact cells and cytosol, indicating that the enzymatic systems of both are sulphydryl-dependent. An apparent effect was also seen with EDTA. Chloroquine and lidocaine, known lysosomotrophic agents, inhibited degradation by the cytosol, while only chloroquine was effective against intact cells. These data are difficult to explain as lysosomotrophic effects since the cytosol had no detectable lysosomal activity. Vinblastine, a compound which inhibits microtubule formation, inhibited degradation as did aprotinin and pepstatin (general protease inhibitors). Bacitracin, methylamine and dansylcadaverine functioned analagously to inhibit glucagon degradation by intact cells and cytosolic fraction alike. With the exception of lidocaine, all 12 inhibitors had the same effect on the cytosol as on the intact cells, indicat- 


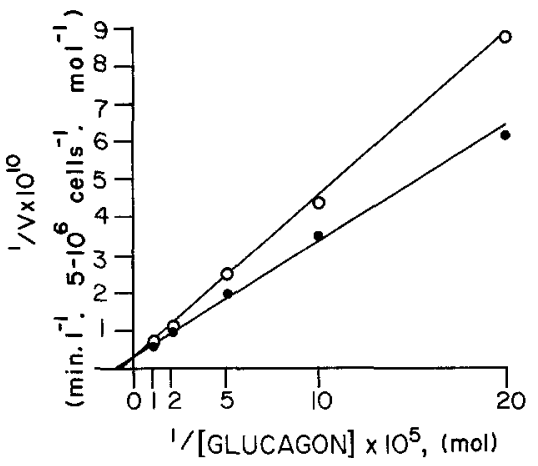

Fig. 6. Double reciprocal plot of glucagon degradation by intact mononuclear cells with and without $2 \times 10^{-7} \mathrm{~mol} / 1$ insulin. Varying concentrations of unlabelled glucagon and tracer concentrations $\left(1 \times 10^{-10} \mathrm{~mol} / \mathrm{l}\right)$ of ${ }^{125} \mathrm{I}$-iodoglucagon were incubated with $10 \times 10^{6}$ mononuclear cells in the presence or absence of unlabelled insulin $\left(2 \times 10^{-7} \mathrm{~mol} / \mathrm{l}\right)$ at $37^{\circ} \mathrm{C}$ for $30 \mathrm{~min} . \mathrm{O}=$ with insulin; $=$ without insulin

Table 5. Effect of inhibitors on cell-associated radioactivity in human mononuclear cells

\begin{tabular}{llll}
\hline Compound & $\begin{array}{l}\text { Concentration } \\
(\mathrm{mmol} / \mathrm{l})\end{array}$ & $\begin{array}{l}\text { Cell-associated } \\
\text { radioactivity }\end{array}$ & $\begin{array}{l}\text { Change } \\
\text { in binding }(\%)\end{array}$ \\
\hline None & - & 2.83 & - \\
p-hydroxy- & 0.1 & 2.73 & -3.5 \\
mercuribenzoate & & 3.36 & +19 \\
N-ethylmaleimide & 0.2 & 1.80 & -36 \\
Bacitracin & $0.1 \mathrm{mg} / \mathrm{ml}$ & 1.40 & -51 \\
& $1.0 \mathrm{mg} / \mathrm{ml}$ & 3.50 & +24 \\
Methylamine & 1.0 & 3.90 & +38 \\
& 10 & 2.61 & -8 \\
Dansylcadaverine & 0.1 & 2.52 & -11 \\
& 0.5 & 4.11 & +45 \\
Chloroquine & 0.1 & 4.09 & +45 \\
Lidocaine & 2.0 & 3.30 & +17 \\
\hline
\end{tabular}

a Pre-incubation for $15 \mathrm{~min}, 25 \times 10^{6}$ cells, $30 \mathrm{~min} 37^{\circ} \mathrm{C}$

Table 6. Glucagon degradation by intact and homogenized human mononuclear cells

\begin{tabular}{lcc}
\hline Preparation & $\begin{array}{l}\text { Glucagon binding } \\
(\%)\end{array}$ & $\begin{array}{l}\text { Glucagon } \\
\text { degraded }(\mathrm{mol} / 1)^{\mathrm{a}}\end{array}$ \\
\hline Intact mononuclear cells & 2 & $3.73 \times 10^{-14}$ \\
Intact monocytes & $>2$ & $16.10 \times 10^{-14}$ \\
Intact lymphocytes & $<1$ & $1.90 \times 10^{-14}$ \\
Homogenized & - & $38.90 \times 10^{-14}$ \\
mononuclear cells & & $53.30 \times 10^{-14}$ \\
$\begin{array}{l}\text { Homogenized monocytes } \\
\quad(97 \% \text { pure) }\end{array}$ & - & $9.00 \times 10^{-14}$ \\
$\begin{array}{l}\text { Homogenized lymphocytes } \\
(98 \% \text { pure })\end{array}$ & - & \\
\hline
\end{tabular}

a Per $5 \times 10^{6}$ cells at $37^{\circ} \mathrm{C}$ for $30 \mathrm{~min}$. Glucagon concentration $10^{-9} \mathrm{~mol} / 1$ ing the importance of cytosolic enzymes in the metabolism of glucagon by intact mononuclear cells.

Several investigators have noted an accumulation of cell-associated radioactivity on target cells treated with enzymatic inhibitors presumably due to the accumulation of undegraded hormone $[11,12]$. Chloroquine and lidocaine gave a $45 \%$ and $17 \%$ increase in cell-associated radioactivity, respectively (Table 5). Similar results were obtained by Hofmann et al., using insulin and cultured hepatoma cells [13]. Bacitracin, methylamine, and dansylcadaverine did not increase consistently cellular radioactivity. In fact, no correlation was seen between the potency of the inhibitor and the accumulation of cellular radioactivity as shown in Table 5 .

\section{Glucagon Degradation by Monocytes and Lymphocytes}

To examine the relative roles of monocytes and lymphocytes in glucagon degradation, highly purified preparations were obtained. A $98 \%$ pure preparation of intact lymphocytes did not degrade significant quantities of glucagon. Monocytes ( $97 \%$ pure) were very active in metabolizing glucagon with $3.73 \times 10^{-14} \mathrm{~mol} / 1$ degraded in $30 \mathrm{~min}$ by $5 \times 10^{6}$ cells.

Homogenized mononuclear cells exhibited $10-20$ times the degrading activity of intact cells, indicating that the bulk of the degrading activity was intracellular. However, homogenized monocyte preparations (enriched four to five times) were only two to three times more active in degrading glucagon than intact monocytes (Table 6). A 98\% pure lymphocyte preparation exhibited significant glucagon-degrading activity only when homogenized.

\section{Discussion}

Monocytes have been reported to be responsible for specific binding of glucagon in mononuclear cell preparations [5]. In the present study, we have demonstrated that mononuclear cells in general and monocytes in particular degrade glucagon in a time, temperature, and cell-concentration-dependent manner. Subcellular fractionation of mononuclear cells revealed that $73 \%$ of the neutral glucagon-degrading activity was in the cytosol, as previously reported for insulin-degrading activity [15]. Quantitatively, neutral activity was three times greater than acidic activity as reported also for liver [16]. Glucagon degrading activity of both intact cells and cytosol fractions was susceptible to the same inhibitors indicating that glucagon degradation by intact cells was a function of cytosolic enzymes, again similar to the liver [16], but different from kidney [17, 18]. A cytosolic enzyme has been isolated from various animal tissues which degrades both insulin and glucagon $[19,20]$. This soluble neutral protease has properties very similar to those of the glucagon degrading activity found in hu- 
man mononuclear cells and may well be the same enzyme.

Kinetic studies gave similar $\mathrm{K}_{\mathrm{m}}$ values for glucagon degradation by intact mononuclear cells, homogenates and cytosol. These values are in the same range as those previously reported for liver and kidney membranes [21] and also similar to the values obtained for insulin protease from rat tissues [18, 19]. Recently, a proteolytic cytosolic enzyme has been isolated from human skeletal muscle which degrades glucagon $\left(\mathrm{K}_{\mathrm{m}}=1.3 \times 10^{-5} \mathrm{~mol} / \mathrm{l}\right)$ and is competitively inhibited by insulin $\left(\mathrm{K}_{\mathrm{I}}=5 \times 10^{-8} \mathrm{~mol} / \mathrm{l}\right)$ [22]. Significantly, glucagon degradation by intact mononuclear cells was competitively inhibited by insulin with a $K_{i}$ value of $3 \times 10^{-7} \mathrm{~mol} / 1$. These data suggest that the cytosolic glucagon-degrading system may be identical to that functioning in intact cells and that this enzyme is similar to insulin protease.

Several investigators have suggested that lysosomes are involved in insulin degradation, both from morphological studies and from studies of lysosomotropic agents such as chloroquine [12, 13, 23]. As reported with insulin, we also found increased cell-associated radioactivity and decreased glucagon degradation with lysosomotrophic compounds. However, cytosolic glucagon-degrading activity, which is devoid of lysosomic activity, was similarly inhibited by lysosomotrophic agents such as chloroquine. These data may imply that the cellular degradation of glucagon in the monocyte, although susceptible to lysosomotrophic agents, is primarily mediated by neutral cytosolic proteases or at least by proteases which fractionate into the $100,000 \mathrm{~g}$ supernatant. Goldstein and Livingston have reached the same conclusion for insulin degradation by rat adipocytes [24].

Davies et al. have recently drawn a correlation between the inhibition of transglutaminase and the inhibition of receptor mediated endocytosis [25, 26]. The transglutaminase inhibitors, bacitracin, methylamine, and dansylcadaverine, were tested for their effects on cell-associated radioactivity and on glucagon degradation by mononuclear cells. All three compounds effectively inhibited degradation of glucagon by both intact cells and cytosol but only methylamine gave an increase in cell-associated radioactivity. These data suggest that transglutaminase inhibitors may have multiple cellular effects as reported previously [27].

In summary, glucagon is rapidly degraded by human monocytes. Cellular glucagon degradation appears to be primarily mediated by a neutral cytosolic sulphydryl-dependent protease(s). This enzyme(s) is similar in the following properties to insulin protease previously identified in other tissue: (1) subcellular location, (2) $\mathrm{K}_{\mathrm{m}}$ for glucagon degradation, (3) $\mathrm{K}_{\mathrm{i}}$ for insulin, and (4) sensitivity to a wide range of inhibitors.

Acknowledgements. The authors are indebted to Ms. M. A. Bobal and R. Graham for technical assistance and to Ms. B.Clark and A. Bo- browski for secretarial support. Supported by research grants from the Veterans Administration, NIH Grant R01AM28592, USPHS Training Grant (Endocrinology/Metabolism) AM07088703, and Short-Term Student Research Training Grant NIH-1-T35-AM07405-02.

\section{References}

1. Exton JM, Park CR (1968) The role of cyclic AMP in the control of liver metabolism. Adv Enzyme Regul 6: 391 - 407

2. Rodbell M (1972) Regulation of glucagon action on its receptors, In: Lefèbvre PJ, Unger PJ (eds) Glucagon: molecular physiology, clinical and therapeutic implications, Pergamon Press, Oxford, pp 61-75

3. Sutherland EW, Robinson GA, Butcher RW (1968) Some aspects of the biological role of adenosine $3^{\prime}, 5^{\prime}$-monophosphate (cyclic AMP). Circulation 37: 279-306

4. Goldstein SM, Blecher M, Binder R, Perrino PV, Recant L (1975) Hormone receptors: binding of glucagon and insulin to human circulating mononuclear cells in diabetes mellitus. Endocr Res Commun 2: 367-376

5. Bhathena S, Louie J, Schechter GP, Redman RS, Wahl L, Recant $\mathrm{L}$ (1981) Identification of human mononuclear leukocytes bearing receptors for somatostatin and glucagon. Diabetes 30: 127-131

6. Boyum A (1968) Separation of leukocytes from blood and bone marrow. IV. Isolation of mononuclear cells and granulocytes from human blood. Scand J Clin Lab Invest 21 (Suppl 97): 77-89

7. Yam LT, Li CT, Crosby WH (1971) Cytochemical identification of monocytes and granulocytes. Am J Clin Pathol 55: 283-290

8. Ly I, Mishell RI (1974) Separation of mouse spleen cells by passage through columns of sephadex G-10. J Immunol Methods 5: $239-244$

9. Huber TH, Solomon SS, Duckworth WC (1980) The time course of insulin degradation in the perifused isolated fat cell. $\mathrm{J}$ Clin Invest 65: 461-468

10. Weissman B, Rowin G, Marshall T, Frederici D (1967) Mammalian alpha-acetylglucosaminidase. Enzyme properties, tissue distribution and intracellular localization. Biochem 6:207-214

11. Marshall S, Olefsky JM (1979) Effects of lysosomotrophic agents on insulin interaction with adipocytes. $J$ Biol Chem 253: 10153-10162

12. Hammons GT, Jarett L (1980) Lysosomal degradation of receptor bound ${ }^{125}$ I-labeled insulin by rat adipocytes. Diabetes 29:475-486

13. Hofmann C, Marsh JW, Miller B, Steiner DF (1980) Cultured hepatoma cells as a model system for studying insulin processing and biological responsiveness. Diabetes 29: 865-874

14. Gambhir KK, Nerurkar SG, Das PD, Archer JA, Henry WL Jr. (1981) Insulin binding and degradation by human erythrocytes at physiological temperature. Endocrinology 109: 1787-1789

15. Powers AC, Solomon SS, Duckworth WC, (1980) Insulin degradation by mononuclear cells. Diabetes 29:27-32

16. Ansorge S, Bohley P, Kirschke H, Langner J, Hanson H (1971) Metabolism of insulin and glucagon. Eur J Biochem 19: 283-288

17. Duckworth WC (1976) Insulin and glucagon degradation by the kidney. I. Subcellular distribution under different assay conditions. Biochim Biophys Acta 437: 518-530

18. Duckworth WC (1976) Insulin and glucagon degradation by the kidney. II. Characterization of the mechanisms at neutral $\mathrm{pH}$. Biochim Biophys Acta 437: 531-542

19. Duckworth WC, Kitabchi AE (1974) Insulin and glucagon degradation by the same enzyme. Diabetes $23: 536-543$

20. Duckworth WC, Heinemann M, Kitabchi AE (1975) Proteolytic degradation of insulin and glucagon. Biochim Biophys Acta 377: $421-430$

21. Duckworth WC (1975) Insulin and glucagon binding and degradation by kidney cell membranes. Endocrinology 102: 1766-1772

22. Neal GW, Kitabchi AE (1982) Insulin degradation by human skeletal muscle. Biochim Biophys Acta 719: 259-266 
23. Barrazone P, Gorden P, Carpentier JL, Orci L, Freychet P, Canivet $B$ (1980) Binding, internalization and lysosomal association of ${ }^{125}$ I-glucagon in isolated rat hepatocytes: a quantitative electron microscope autoradiographic study. J Clin Invest 66: 1081-1093

24. Goldstein HJ, Livingston JN (1981) An evaluation of the importance of lysosomal and neutral cytosol proteases in insulin degradation by adipocytes. Endocrinology 108: 953-961

25. Davies PJA, Davies DR, Levitski A, Maxfield FR, Milhaud P, Willingham MC, Pastan IH (1980) Transglutaminase is essential in receptor-mediated endocytosis of 2-macroglobin and polypeptide hormones. Nature 283: 162-167

26. Maxfield FR, Davies PJA, Klempner L, Willingham MC, Pastan IH (1979) Epidermal growth factor stimulation of DNA synthesis is potentiated by compounds that inhibit its clustering in coated pits. Proc Natl Acad Sci 76: 5731-5735
27. Ahmed CE, Niswender GD (1981) Internalization and degradation of human chorionic gonadotropin in ovine luteal cells: Effects of inhibitors of transglutaminase. Endocrinology 109: 1388-1393

Received: 1 December 1982

and in revised form: 3 August 1983

Dr. S.S.Solomon

VA Medical Center

Research Service (151)

1030 Jefferson Avenue

Memphis, TN 38104, USA 